\title{
Situs-Situs Sejarah di Lampung Sebagai Sumber Belajar Sejarah
}

\author{
Aprilia Triaristina $^{\left.1^{*}\right)}$; Valensy Rachmedita ${ }^{2}$
}

Published online: 5 December 2021

\begin{abstract}
Memanfaatkan situs sejarah sebagai sumber belajar merupakan hal penting, sebab situs sejarah merupakan salah satu sumber sejarah yang dapat memberikan gambaran suatu peristiwa dengan lebih konkrit kepada mahasiswa. Lampung memiliki beberapa situs sejarah yang dapat digunakan sebagai sumber belajar dan situs-situs sejarah di Lampung memiliki kesesuaian antara materi yang terkandung dalam situs dengan materi perkuliahan yang ada pada kurikulum Program Studi Pendidiakn Sejarah FKIP Universitas Lampung. Salah satu prinsip dari pelaksanaan kurikulum juga ada yang mendukung dalam pelaksanaan pemanfaatan situs sejarah sebagai sumber belajar. Hal tersebut menjadi alasan mengapa keberadaan situs sejarah di Lampung perlu untuk diteliti sejauh mana tingkat efektifitasnya sebagai sumber belajar. Penelitian ini mengambil tiga rumusan masalah yang tujuan akhirnya adalah untuk menilai sejauh mana efektifitas pemanfaatan situs sejarah di Lampung sebagai sumber belajar dalam mata kuliah Sejarah Indonessia pada masa Prasejarah pada mahasiswa program studi pendidikan Sejarah. Penelitian ini menggunakan pendekatan deskriptif kualitatif dengan lokasi penelitian Program Studi Pendidikan Sejarah. Informan adalah dosen pendidikan Sejarah dan mahasiswa. Teknik pengumpulan data yang digunakan adalah observasi, wawancara dan dokumentasi. Teknik pemeriksaan keabsahan data menggunakan teknik triangulasi sumber. Analisis data yang digunakan adalah model analisis interaktif.
\end{abstract}

Keywords: Situs Sejarah, Sumber belajar

\section{PENDAHULUAN}

Hakikatnya sejarah merupakan mata kuliah yang menekankan pada pengembangan konsep serta struktur peristiwa. Mata kuliah sejarah memiliki arti strategis dalam pembentukan watak dan peradaban bangsa yang bermartabat serta dalam pembentukan manusia Indonesia yang memiliki rasa kebangsaan dan cinta tanah air. Bangsa yang tidak mengenal sejarahnya manusia dapat diibaratkan seorang individu yang telah kehilangan memorinya, ialah orang yang pikun atau sakit jiwa, maka dia kehilangan kepribadian atau identitasnya (Kartodirdjo, 1993). Namun kadangkala pembelajaran sejarah sering dianggap hanya sebagai urutan peristiwa. Hal tersebut terjadi disebabkan karena metode pembelajaran yang digunakan oleh dosen kurang bervariatif sehingga pemahaman mengenai hakikat dibalik peristiwa sejarah kurang dapat dipahami oleh mahasiswa. Menurut (Agus Supriyono, 2010) dalam makalahnya menyatakan bahwa berdasarkan survey yang dilakukan oleh salah satu media

\footnotetext{
$\overline{1,2}$ Departemen Pendidikan Sejarah Universitas Lampung

*) corresponding author

Aprilia Triaristina

Program Studi Pendidikan Sejarah

Fakultas Keguruan dan Ilmu Pendidikan Universitas Lampung Jalan Prof. Dr. Soemantri Brojonegoro No. 01 Bandar Lampung

Email: aprilia@fkip.unila.ac.id
}

masa di Surabaya menunjukan hasil bahwa mata pelajaran yang membosankan. Metode pembelajaran yang tidak variatif tentunya yang dilakukan khusunya pada mata pelajaran sejarah. Pembelajaran dengan memanfaatkan situs-situs sejarah sebagai sumber belajar dapat menjadi salah satu alternatif dalam mengatasi masalah metode mengajar yang monoton, sehingga pembelajaran dapat menjadi lebih menarik dan kreatif.

Manusia merupakan makhluk yang berbudaya dan berkarya, maka dalam perjalanan hidupnya dari waktu ke waktu senantiasa ditandai dengan bukti dan karya sebagai peninggalan yang bentuk dan jenisnya sangat ditentukan atau diarnai oleh situasi yang dilalui dan dialaminya, (Djoko, 2003) menjelaskan budaya atau kebudayaan adalah seluruh hasil usaha manusia dengan budinya berupa segenap sumber jiwa, yakni cipta rasa dan karsa. Perwujudan kebudayaan adalah benda-benda yang diciptakan oleh manusia sebagai makhluk yang berbudaya, berupa perilaku dan benda-benda yang bersifat nyata, missal pola-pola perilaku, bahasa, peralatan hidup, organisasi sosial, religi, seni, situs peninggalan sejarah yang kesemuanya ditujukan untuk membantu manusia dalam melangsungkan kehidupan bermasyarakat. Kebudayaan sebagai sesuatu yang turun temurun dari satu generasi ke genarasi yang lain, kebudayaan mengandung keseluruhan pengertian, nilai, norma, ilmu pengetahuan serta keseluruhan struktur-struktur sosial religius, dan lain-lain, tambahan lagi segala pernyataan intelektual dan artistik yang menjadi ciri khas suatu masyarakat (Munandar, 2010). 
Pemanfaatan lingkungan situs peninggalan sejarah sebagai sumber belajar sejarah akan menimbulkan persepsi yang positif dan membuat partisipasi siswa cukup tinggi di dalam ikut melestarikan (Semiawan, 1992). Tanggapan positif dan munculnya keaktifan mahasiswa ini merupakan faktor penentu juga bagi keberhasilan mahasiswa. Dengan demikian diharapkan prestasi mahasiswa melalui pemanfaatan sumber belajar situs sejarah akan mengingatkan prestasi mereka.

Menurut (Wasino, 2007) dalam bukunya menyatakan sumber sejarah berdasarkan bentuknya dapat dibagi menjadi tiga macam yaitu sumber benda (bangunan, perkakas, senjata), sumber tertulis (dokumen), sumber lisan (hasil wawancara). Situs sejarah termasuk dalam kategori sumber benda sebab bentuk dari situs-situs sejarah yang ada di Lampung berupa peninggalan berupa menhir, dolmen, punden berundak, batu mayat, batu tegak, manik-manik, prasasti, dan peninggalan prasejarah megalitikum yang ada di Lampung berupa peninggalan sejarah maupun sebagai simbol suatu peristiwa sejarah.

Berbicara soal sejarah berarti berbicara tentang rangkaian perkembangan peristiwa yang menyangkut kehidupan manusia diwaktu yang lampau dalam berbagai aspeknya. Kemudian apabila kita berbicara tentang pengajaran sejarah itu berarti membawa rangkaian peristiwa kehidupan manusia kedalam kelas untuk diinformasikan dan disimak (Widja, 1989). Peristiwa masa lampau yang diangkat kembali melalui prosedur penelitian sejarah oleh ahli dianggap memiliki manfaat atau kegunaan bagi kehidupan manusia pada masa sekarang yang mempelajarinya, antara lain untuk penddidikan, memberi pengajaran (instruktif), memberi ilham (inspiratif), memberi kesenangan (rekreatif). (Wasino, 2007). Situs sejarah tentu memiliki peran yang penting dalam pembelajaran sejarah kaitannya dengan manfaat sejarah sebagai pendidikan. Situs sejarah dapat digunakan sebagai sumber sejarah yag menyajikan berbagai fakta yang lebih dekat dengan kebenaran serta memberikan fakta yang lebih dapat membantu mahasiswa dalam memahami dan mencoba merangkai peristiwa yang terjadi di masa lampau.

Pembelajaran sejarah dapat didukung dengan memanfaatkan benda-benda yang ada disekitar mahasiswa. Salah satu upaya untuk meningkatkan respon dan minat mahaiswa terhadap mata kuliah Indonesia Pada Masa Prasejarah salah satunya dengan menciptakan pola pembelajaran yang terkait dengan kondisi dan situasi lingkungannya. Kegiatan dalam perkuliahan ini memerlukan sebuah medium untuk mengembangkan rasa kepedulian dan ketertarikan akan ranah kedaerahan mereka, untuk selanjutnya digali lebih dalam tentang apa yang pernah ada dalam lintasa masa lalu didaerahnya (Wasino, 2009). Salah satu diantaranya adalah situs sejarah. Menurut William Haviland (dalam Warsito, 2012) mengatakan bahwa situs merupakan tempat-tempat ditemukan peninggalan-peninggalan arkeologi di kediaman makhluk manusia zaman dahulu dikenal dengan situs. Situs-situs atau peninggalan sejarah dapat dimanfaatkan dalam perkuliahan, sehingga terdapat pemanfaatan terhadap aset sejarah lokal dan terwujudlah pembelajaran yang kontekstual.

Fenomena yang terjadi pada saat ini dikalangan mahasiswa, mereka lebih tertari memahami materi tentang sejarah yang membahas di luar Indonesia, seperti Sejarah Eropa, dan Sejarah Afrika. Mahasiwa sering melupakan materi-materi yang bersifat keindonesiaan, seperti masa prasejarah di daerah Lampung ataupun sejarah nasional Indonesia. Maka dalam meningkatkan kesadaran mahasiswa, pembelajaran sejarah seharusnya dapat meningkatkan gairah dan mendorong serta meningkatkan kemampuan berfikir kritis dan historis (Seixas \& Peck, 2004; Sulistyo, 2016). Pendidik harus dapat memberikan sebuah formula suatu pembelajaran sejarah dengan mempelajari permasalahan dari pembelajaran sejarah yang terjadi secara umum selama ini antara lain materi dan sumber belajar yang ada di sekitar peserta didik (Brophy \& vansledright, 1997).

Pendidik yang berperan sebagai pengampu mata kuliah perlu menghadirkan sebuah sumber-sumber sejarah atau membawa langsung peserta didik ke sumber-sumber tersebut sebagai bukti sejarah yang dapat dikolaborasikan dengan metode karya wisata/fieldtrip menurut (Seniawan, 1990) bahwa pengalaman belajar langsung lebih baik dari pada tidak langsung. Banyak peninggalan sejarah di Indonesia yang dapat dijadikan sebagai sumber belajar. Salah satunya di Provinsi Lampung yang terdapat di Lampung Barat yaitu situs Batu Brak, di Lampung Selatan situs Palas Pasemah, dan di Tanggamus situs Batu Bedil. Situs-situs ini dapat dijadikan sebagai sumber belajar sejarah bagi mahasiswa sebagai bahan untuk merekontruksi dan mempelajrai cikal bakal terbentuknya sebuah provinsi Lampung. Menurut Undang-undang No. 11 Tahun 2010 tentang Cagar Budaya dalam pasal 1 yaitu:" cagar budaya adalah warisan budaya bersifat kebendaan berupa benda cagar Budaya, Bangunan Cagar Budaya, Struktur Cagar Budaya, Situs Cagar Budaya di darat dan/ atau di air yang perlu dilestarikan keberadaannya karena memiliki nilai penting bagi sejarah, ilmu pengetahuan, pendidikan, agama, dan/atau kebudayaan melalui proses penetapan" (Undang-Undang Nomor 11 Tahun 2010 Tentang Cagar Budaya, 2010).

Situs-situs sejarah memiliki kontribusi yang besar kepada warga masyarakat sekitar dan yang lebih utama dan penting dalam bidang penelitian (Maslina, 2014). Situs-situs bersejarah di Indonesia sangatlah banyak tetapi belum dipergunakan secara maksimal dalam proses belajar oleh guru sejarah atau dosen guna untuk kepentingan pembelajaran sejarah (Nababban, dkk, 2019). Situs sangat penting untuk ditunjukan agar terhindar dari kerusakan manusia dan alam serta mengalami kepunahan. Untuk harapan kedepan situs sejarah dapat terawat dan dikembangakan sebagai objek belajar dan diturunkan kepada generasi muda dalam keadaan yang baik dan utuh. Situs-situs sejarah banyak yang terbengkalai di lingkungaan sekitar, tidak terawat dan tidak mendapat perhatian padahal situs dapat dimanfaatkan sebagai sumber belajar yang relevan (Azaryahu \& Foote, 2008; Summbery-Murray, 2001).

Menurut (Wasino, 2007) dalam bukunya menyatakan sumber sejarah berdasarkan bentuknya dapat dibagi menjadi tiga macam yaitu sumber benda (bangunan, perkakas, senjata), sumber tertulis (dokumen), sumber lisan (hasil wawancara). Situs sejarah termasuk dalam kategori sumber benda sebab bentuk dari situs-situs sejarah yang ada di Lampung berupa peninggalan berupa menhir, dolmen, punden berundak, batu mayat, batu tegak, manik-manik, prasasti, dan peninggalan prasejarah megalitikum yang ada di Lampung berupa peninggalan sejarah maupun sebagai simbol suatu peristiwa sejarah.

Berbicara soal sejarah berarti berbicara tentang rangkaian perkembangan peristiwa yang menyangkut kehidupan manusia diwaktu yang lampau dalam berbagai aspeknya. Kemudian apabila kita berbicara tentang pengajaran sejarah itu berarti membawa rangkaian peristiwa kehidupan manusia kedalam kelas untuk diinformasikan dan disimak (Widja, 1989). Peristiwa masa lampau yang diangkat kembali melalui prosedur penelitian sejarah oleh ahli dianggap memiliki manfaat atau 
kegunaan bagi kehidupan manusia pada masa sekarang yang mempelajarinya, antara lain untuk penddidikan, memberi pengajaran (instruktif), memberi ilham (inspiratif), memberi kesenangan (rekreatif). (Wasino, 2007). Situs sejarah tentu memiliki peran yang penting dalam pembelajaran sejarah kaitannya dengan manfaat sejarah sebagai pendidikan. Situs sejarah dapat digunakan sebagai sumber sejarah yag menyajikan berbagai fakta yang lebih dekat dengan kebenaran serta memberikan fakta yang lebih dapat membantu mahasiswa dalam memahami dan mencoba merangkai peristiwa yang terjadi di masa lampau.

Pemanfaatan situs sejarah sebagai sumber belajar sejarah dapat memberikan gambaran yang lebih nyata kepada peserta didik sehingga mereka diharapkan dapat memahami peristiwa sejarah secara lebih nyata, tidak hanya dalam gambaran yang masih abstrak. Pemanfaatan situs sejarah dapat dialkukan dengan berbagai cara, misalnya saja melalui film dokumenter atau media pembelajaran audio visual, mengenai situs tersebut, selain itu juga dapat dengan melakukan kunjungan langsung ke situs-situs sejarah, ataupun dengan menunjukan gambar bagian-bagian situs dan lain-lain.

Penemuan situs-situs sejarah sangat besar manfaatnya juga sejarah Indonesia, sebab dengan adanya penemuanpenemuan situs sejarah tersebut dapat memperkaya cerita sejarah Indonesia. Selain itu, keberadaan situs-situs sejarah tersebut dapat digunakan sebagai pembanding untuk mengukur kredibilitas sumber sejarah atau sebagai verifikasi sumber sejarah yang sudah diakui sebelumnya. Menurut (Wasino, 2007) dalam bukunya menyatakan bahwa untuk melakukan verifikasi atau kritik sumber, ada tiga cara yaitu kritik ekstern atau uji otentitas sumber, verifikasi kredibilitas sumber dan kolaborasi atau dukungan bagi sumber lain. Penemuan situs sejarah baru tentunya akan dapat menjadi dukungan bagi sumber yang telah ada ataupun pembanding untuk sumber yang ada tersebut. Proses pembanding tersebut dinamakan kolaborasi atau dalam bahasa penelitian kualitatif dikenal dengan triangulasi.

Lampung merupakan salah satu provinsi yang memiliki peninggalan sejarah yang cukup kaya, hanya saja masyarakatnya kurang menyadarinya. Situs Pugung Raharjo di Lampung Timur, Situs Batu Berak di Lampung Barat, Situs Batu Bedil di Tanggamus, dan Prasati Palas Pasemah di Lampung Selatan. Kurangnya perhatian pemerintah serta publikasi yang masih minim menjadi salah satu penyebab kurang dikenalnya situs-situs tersebut tersebut yang berakibat pada minimnya pemanfaatan situs sejarah yang ada di Lampung tersebut bagi pembelajaran Sejarah Indonesia Pada Masa Prasejarah.

Pada kurikulum Program Studi Pendidikan Sejarah FKIP Universitas Lampung terdapat mata kuliah Indonesia Pada Masa Prasejarah dan Sejarah Pada Masa Hindu-Budha. Akan tetapi sampai sekarang pembelajarannya masih belum maksimal, hal ini disebabkan karena terbatasnya bahan ajar yang menjadi sumber belajar, dan juga minimnya penggunaan sarana media pembelajaran. Peninggalan situs-situs prasejarah di Lampung merupakan salah satu materi yang termuat dalam mata kuliah Indonesia Pada Masa Prasejarah, dan memerlukan sarana dan prasarana agar pembelajaran dapat dipahami, dipelajari, dan diteladani nilai-nilai yang terkandung di dalamnya untuk membentuk kepribadian secara utuh. Berdasarkan latar belakang di atas maka peneliti tertarik untuk meneliti masalah tentang efektivitas pemanfaatan situs-situs sejarah di Lampung sebagai sumber belajar sejarah pada mahasiswa Program Studi Pendidikan Sejarah.

\section{TINJAUAN PUSTAKA}

Setiap daaerah tentu memiliki kisah dan sejarah terssendiri dalam perjalannnya. Begitu pula dengan peninggalan-peninggalan sejarahnya, tentu memiliki keberagaman sesuai dengan khas masing-masing daerah. Peninggalan-peninggalan sejarah tersebut tentunya memiliki arti penting sebagai bukti dari peristiwa bersejarah dimasa lampau pada daerah tersebut. Lampung juga memiliki berbagai peninggalan sejarah yang menjadi sebuah bukti bahwa Lampung pernah mengalami masa lampau yang cukup penting dalam perjalanan sejarah, Lampung sehingga perlu untuk mengetahui dan mempelajari serta memanfaatkan peninggalan sejarah tersebut sebagai sumber belajar terutama bagi kalangan mahasiswa. Berapa peninggalan sejarah yang ada di Lampung yaitu Situs Taman Purbakala Pugung Raharjo, Situs Megalitikum Kebon Tebu/Batu Berak, Situs Prasasti Batu Bedil, dan Situs Prasasti Palas Pasemah.

\section{Situs Batu Brak}

Peninggalan situs Batu Berak terdiri dari dolmen, menhir, batu datar, manik-manik kaca dan batu, keramik lokal dan asing, batu umpak serta batu lumpang, dibangun pada suatu bukit kecil yang dikelilingi oleh sungai kecil sawah dan empang. Areal situs berukuran sekitar 3 ha. Menurut (Soejono, 1975) menyatakan demikian tradisi pendirian bangunan-bangunan megalitik (mega berarti besar, lithos berarti batu) selalu berdasarkan kepercayaan akan adanya pengaruh kuat dari yang telah mati, terhadap kesejahteraan maasyarakat dan pengaruh kuat dari yang telah mati terhadap kesejahteraan maasyaarakat dan kesuburan tanaman. Menurut UU No 11 tahun 2010 pasal 1 (2010) berbunyai: cagar budaya adalah waarisan budaya, struktur cagar buaya, situs cagar budaya, dan kawasan cagar budaaya di darat dan/ atau di air yang perlu dilesstarikan keberadaannya karenaa memiliki nilai penting bagi sejarah, ilmu pengetaahuan, pendidikan, agama, dan/atau kebudayaan melalui proses penetapan. Jika dikaitkan dengan situs Batu Berak, maka dapat disimpulkan pula bahwa nilai-nilai tersebut Nampak pada situs Batu Berak dalam wujud bangunan-bangunan atau bendaa hasil karya manusia pada situs Batu Berak pada masa megalitikum.

Menurut Galdrnen dalam (T. Abdullah, 2012) menyatakan bahwa kebudayaan megaliti yang masuk ke Indonesia dapat dibagi dalam dua gelombang. Gelombang pertama terjadi pada zaman Neolitik akhir kira-kira tahun 2.500-1.500 SM yang masuk ke Indonesia dibawa oleh imigran Tonkin menuju Malaysia Barat ke Sumatra selanjutnya berlanjut ke Jawa, Nuasa Tenggara dan menyebar ke Kalimantan.

\section{Situs Prasasti Batu Bedil}

Situs Batu Bedil secara administratif berada di Gunung Meraksa, kecamatan Pulau Panggung, Kabupaten Tanggamus. Secara geografis lokasi ini berada di wilayah hulu Way Sekampung. Bentag alam daerah berupa pedataran bergelombang. Situs Batu Bedil merupakan kompleks megalitik memiliki luas sekitar 100 x 500 m. Situs terbagi menjadi kompleks Batu bedil 1 berada di wilayah barat dan kompleks Batu Bedil II berada di wilayah timur. Kedua lokasi tersebut berjarak sekitar $100 \mathrm{~m}$. Kompleks Batu Bedil I berada pada lahan seluas 100 x 50 $\mathrm{m}$. Kompleks ini berada di lahan datar yang lebih tinggi dari daerah sekitarnya. Pada lahan ini terdapat prasasti dan 
sekelompok menhir yang membentuk formasi segi empat. Selain itu juga terdapat sebaran batu-batu besar.

Prasasti dituliskan pada sebongkah batu berukuran panjang $185 \mathrm{~cm}$, lebar $72 \mathrm{~cm}$, tebal $55 \mathrm{~cm}$. Tulisan prasasti digorsekan pada bagian batu yang menghadap ke utara. Prasasti terdiri atas 10 baris dengan tinggi huruf sekitar 5 $\mathrm{cm}$. Pada bagian bawah bingkai terdapat goresan membentuk Padma atau bunga tertai. Kondisi huruf sudah aus sehingga banyak huruf yang sudah tidak terbaca lagi. Di sebelah barat prasasti terdapat 14 menhir yang membentuk formasi segi empat. Menhir-menhir terebut merupakan batu alam yang tidak menunjukan tanda-tanda pengerjaan oleh manusia. Selain menhir di lahan ini juga terdapat sejumlah batu besar. Dilihat dari bentuknya batubatu tersebut kemungkinan sebagai menhir maupun dolmen. Pada permukaan lahan sering terlihat adanya benda artefaktual berupa pecahan keraik dan tembikar.

Situs Batu Bedil mengambarkan adanya persentuhan religi masyarakat dengan Buddha. Prasasti Batu Bedil berisi mantra. Tulisan pada prasasti Batu Bedil sudah sangat aus sehingg sulit dibaca. Berdasarkan perbandingan hurufnya. Prasasti Batu Bedil diperkirakan berasal dari akhir abad ke9 atau awal abad ke-10. Beberapa kata yang terbaca adalah Namo Bhagawate pada baris pertama Swaha pada baris ke sepuluh. Menurut Soekmono, berdasarkan kata-kata tersebut menunjukan bahwa Prasasti Batu Bedil berisi tentang mantra agama Budha (Soekmono, 1985).

Lokasi Prasasti Batu Bedil berada di lahan yang dibatasi dua sungai. Tingalan arkeologis lainnya yang ditemukan adalah bangunan megalitik. Di Batu Bedil I terdapat sekumpulan menhir, batu datar, dan prasasti sedangkan di Batu Bedil II ditemukan menhir, dolmen, batu bergores, dan lumpang batu. Di antara tinggalan monumental tersebut tersebar pecahan keramik dan gerabah yang menunjukan bekas pemukiman. Berdasarkan kondisi seperti ini memperhatikan bahwa pada permukiman masyarakat terdapat juga monumen-monumen untuk sarana pemujaan kepada arwah nenek moyang. Lahan berupa punggungan bukit yang diapit dua aliran sungai merupakan lokasi ideal untuk permukiman karena secara alami sungai dapat dijadikan benteng pertahanan dan sekaligus menyediakan keperluan air.

Kehidupan religi masyarakat ketika itu terlihat dari prasasti dan tinggalan monumental. Antara isi prasasti Batu Bedil dengan tinggalan arkeologis lain terlihat ada kesamaan watak yaitu menyangkut aspek religi. Isi prasati berupa mantra dalam ajaran Buddha sedangkan tinggalan monumental yang ada merupakan bangunan untuk sarana ritual dalam tradisi megalitik. Menhir, dolemen, batu datar, dan kaaitannya dengan sengaja di suatu tempat untuk memperingat arwah nenek moyang dan pengharapan kesejahteraan bagi yang masih hidup (Bintarti, 2010). Menurut H.R van Heekeren, dolmen merupakan peninggalan masyarakat pendukung budaya megalitik yang bis dikaitkan dengan upacara penguburan. Selain itu dolmen berfungsi sebagai tempat duduk yang dipergunakan dalm upacara pemujaan kepada arwah leluhur. Dolmen yang tersusun dengan peninggalan megalitik lainnya menunjukan bahwa olmen tersebut merupakan perangkat penting yang dipergunakan dalam kegiatan yang berhubungan dengan pemujaan arwah leluhur (Laili, 2004).

\section{Sumber Belajar}

Secara sederhana sumber belajar dapat dirumuskan sebagai segala sesuatu yang dapat memberikan kemudahan kepada peserta didik dalam memperoleh sejumlah informasi, pengetahuan, pengalaman dan ketrampilan dalam proses belajar mengajar (Mulyasa, 2003). Selain itu, sumber belajar dapat pula diartikan sebagai segala macam yang ada diluar diri peserta didik yang memungkinkan (membuahkan) terjadinya proses belajar (Rohani, 1997:102). Menurut Asosiasi Teknologi Komunikasi Pendidikan (AECT) sumber belajar adalah semua sumber (baik berupa data, orang, atau benda) yang dapat digunakan untuk member fasilitas (kemudahan) belajar bagi siswa (Sudjarwo,1989).

Sumber belajar itu meliputi pesan, orang, bahan, peralatan, teknik, dan lingkungan/latar. Pesan adalah ajaran atau informasi yang akan disampaikan oleh komponen belajar lain, yang dapat berupa ide, fakta, ajaran, nilai dan data. Dalam sistem pembelajaran, maka pesan ini berupa seluruh mata pelajaran yang disampaikan kepada siswa. Orang adalah manusia yang berperan sebagai pencari, penyimpan, pengolah dan penyaji pesan. Misalnya saja guru, dosen, instruktur, tenaga ahli dan sebagainya. Bahan merupakan perangkat lunak (software) yang mengandung pesan belajar, yang biasanya disajikan menggunakan peralatan tertentu. Teknik yaitu prosedur atau langkah-langkah tertentu yang disiapkan untuk menggunakan bahan, alat, lingkungan dan orang untuk menyampaikan pesan. Sedangkan lingkungan/latar adalah situasi di sekitar terjadinya proses belajar mengajar dimana pembelajar menerima pesan. Sebagaimana disebutkan oleh I Gde Widja (1989: 61-68) sumber belajar dalam pembelajaran sejarah yang terpenting yaitu:

a. Peninggalan sejarah seperti jejak tertulis (dokumen) jejak benda dan jejak lisan. Jejak benda seperti candi, monumen, museum, jejak lisan pelaku sejarah, tokoh pejuang.

b. Sumber belajar yang sudah tersedia yang tinggal memanfaatkan untuk pengajaran sejarah meliputi antara lain:

1. Monumen didirikan untuk menandai dan mengenang suatu peristiwa bersejarah pada suatu tempat. Dalam monumen digambarkan jalan peristiwa dalam bentuk relief.

2. Perpustakaan sebagai penyimpanan koleksi bahan pustaka yang diproses secara sistematis agar cepat dan mudah melayani kebutuhan pemakaian jasa perpustakaan koleksi perpustakaan menyangkut buku sejarah

3. Pelaku sejarah atau tokoh pejuang maupun sejarawan serta seorang guru sejarah merupakan diantara sumber belajar sejarah

4. Situs: Peninggalan sejarah seperti situs purbakala, candi, masjid, kraton, makam, tokoh sjarah maupun sumber sejarah. Kompleks percandian menunujukan bahwa wilayah tersebut merupakan pusat pengembangan dan kegiatan pada masa lalu atau jaman dahulu. Gedung sejarah menunjukan pula bahwa disitu pernah ada pusat aktifitas suatu masyarakat. Masjid bersejarah mengisyaratkan bahwa disitu juga pernah ada pusat pengembangan dan kegiatan para tokoh utama atau wali dan lain-lain dalam mendalami agama Islam. Kraton menunjukan sebagai pusat pemerintahan dari suatu kerajaan.

5. Museum: Merupakan tempat menyimpan benda-benda peninggalan sejarah.

6. Masyarakat sebagai sumber belajar menyimpan pesanpesan sejarah yang berupa legenda, cerita rakyat, kisahkisah kepahlawanan maupun pesan kebudayaan lainnya. 


\section{Pembelajaran Sejarah}

Sejarah dalam fungsinya bukan hanya sekedar mengingat masa lampau tapi sejarah adalah cerminan aktivitas kehidupan manusia dimasa lampau pada masa kini. Sejarah ibarat kompas bagi kehidupan atau dasar bagi seorang pilot untuk mengambil keputusan, karena sejarah adalah kristalisasi dari semua pengetahuan, semua ilmu dan semua yang telah dipelajari sejak manusia ada. Kondisi yang demikian, memungkinkan sejarah untuk mengangkat nilai-nilai universal yang terkandung dari setiap bentuk budaya manusia. Dengan demikian pendidikan sejarah tidak hanya diarahkan untuk menanamkan pemahaman masa lampau hingga masa kini, menumbuhkan rasa tentang adanya perkembangan masyarakat kebangsaan dan cinta tanah air serta rasa bangga sebagai warga Indonesia dan memperluas wawasan hubungan masyarakat antar bangsa di dunia. (Depdikbud RI, 1998).

\section{METODE PENELITIAN}

Penelitian ini menggunakan metode penelitian deskriptif, yaitu untuk mendeskripsikan teantang pemanfaatan situs Purbakala Pugung Raharjo sebagai sumber belajar. Metode penelitian deskriptif merupakan metode penelitian yang digunakan untuk menggambarkan fenomena-fenomena yang telah berlagsung saat ini atau pada saat yang sudah lampau (Syaodij, 2010). Penelitian deskriptif dapat digunakan untuk menunjukan fenomenafenomena yang ada yaitu, berupa fenomena alamiah maupun fenomena yang dibuat oleh manusia. Fenomena yang terjadi itu bisa berupa wujud dari aktivitas, karakteristik, perubahan yang terjadi, hubungan, serta kesamaan dan perbedaan dari fenomena tersebut. Dalam penelitian deskriptif ini menggunakan pendekatan kualitatif. Pengumpulan data dilakukan dengan cara: 1) Studi kepustakaan untuk mencari sumber-sumber yang berkaitan situs Pugung Raharjo, 2) Observasi dilakukan secara langsung ke situs Pugung Raharjo, serta 3) Wawancara, untuk menggali lebih dalam tentang bagaimana pemanfaatan situs Pugung Raharjo sebagai sumber belajar Sejarah. Teknis analisis yang digunaakan yaitu teknis interaktif menurut (Miles, M.B \& Huberman, 1984). Teknis analisis ini terdiri dari tiga komponen analisis yang akan digunakan yaitu meliputi reduksi data, sajian data dan penerikan kesimpulan atau verifikasi. Dalam menguji keabsahan data menggunakan triangulasi pengumpulan data.

Beberapa tahapan penelitian adalah sebagai berikut: Reduksi data yakni dengan mengklasifikasikan data dari hasil wawancara yang mendalam, observasi dan dokumentasi. Penyajian data dilakukan oleh peneliti setelah reduksi data, yang tertuang dalam bentuk teks daan bersifat deskriptif. Proses selanjutnya adalah penarikan kesimpulan dan verifikasi data yang dilakukan dengan cara melihat dari makna dan hubungan-hubungan data yang diperoleh dari hasil observasi, wawancara secara mendalam, dan dokumentasi. (Perdana, Sumargono \& Rachmedita, 2019).

\section{HASIL PENELITIAN}

Provinsi Lampung terletak diantara $105^{\circ} 45-103^{\circ}$ Bujur Timur dan $3^{\circ} 45-6^{\circ} 45$ Lintang Selatan. Provinsi Lampung memiliki 13 Kabupaten dan 2 pemerintahan Kota. Provinsi Lampung memiliki peninggalan-peninggalan Sejarah yang tersebar di daerah kabupaten. Peninggalan-peninggalan sejarah yang ada di Lampung paling banyak yaitu tentang situs-situs sejarah peninggalan Megalitikum. Lampung sangat jarang atau dikaitkan dengan sejarah nasional, bukan berarti Lampung tidak memiliki sejarah seperti halnya daerah-daerah lain. Lampung memiliki beerbagai sejarah dari masa ke masa yang tidak kalah menarik dengan sejarah-sejarah yang ada di daerah-daerah lain. Lampung juga memiliki berbagai peninggalan yang menjadi bukti bahwa Lampung pernah mengalami masa lampau yang cukup penting dalam perjalanan sejarahnya. Peninggalan-peninggalan tersebut merupakan bukti-bukti yang dapat dijadikan sumber melacak ataupun merekontruksi perjalanan sejarah yang pernah terjadi di Lampung.

Diantara peninggalan-peninggalan sejarah yang ada di Lampung, beberapa diantranya memiliki peran penting dalam Sejarah Lmapung yang memiliki keterkaitan sejarah yang lebih luas, dalam artian bukan hanya merupakan sejarah lokal Lampung. Beberapa diantara peninggalaneninggalan sejarah yang ada di Lampung memeliki keterkaitan dengan sejarah nasional yang walaupun tidak semua masyarakat Lampung mengetahui keberadaannya. Bentuk peninggalan-peningalan sejarah yang ada di Lmapung sebagaian besar berupa situs-situs sejarah. Peninggalan-peninggalan tersebut memiliki karakter dan sejarah yang berbeda-beda. Namun pada dasarnya masingmaasing peninggalan tersebut merupakan bukti yang dapat dijadikan sebagai sumber sejarah untuk melacak dan merangkai peristiwa sejarah yang pernah terjadi di Lampung.

Maing-masing peinggalan sejarah terssebut memiliki kekurangan dan kelebihan dalam keberadaannya sebagai situs sejarah, namun setiap peninggalan-peninggalan sejarah tersebut tetap bisa dikatakan layak untuk dijadikan sumber sejarah bagi mahasiswa yang disesuaikan dengan materi yang berkaitan. Di bawah ini merupakan rinciaan dan alasan dari masibg-masing peninggalan sejarah yang ada di Lampung sehingga dapat dijadikan sebagai sumber belajar pada pembelajaran sejarah.

\section{Situs Batu Brak}

Peninggalan situs Batu Berak terdiri dari dolmen, menhir, batu datar, manik-manik kaca dan batu, keramik lokal dan asing, batu umpak serta batu lumpang, dibangun pada suatu bukit kecil yang dikelilingi oleh sungai kecil sawah dan empang. Areal situs berukuran sekitar 3 ha. Menurut (Soejono, 1975) menyatakan demikian tradisi pendirian bangunan-bangunan megalitik (mega berarti besar, lithos berarti batu) selalu berdasarkan kepercayaan akan adanya pengaruh kuat dari yang telah mati, terhadap kesejahteraan maasyarakat dan pengaruh kuat dari yang telah mati terhadap kesejahteraan maasyaarakat dan kesuburan tanaman. Menurut UU No 11 tahun 2010 pasal 1 (2010) berbunyai: cagar budaya adalah waarisan budaya, struktur cagar buaya, situs cagar budaya, dan kawasan cagar budaaya di darat dan/ atau di air yang perlu dilesstarikan keberadaannya karenaa memiliki nilai penting bagi sejarah, ilmu pengetaahuan, pendidikan, agama, dan/atau kebudayaan melalui proses penetapan. Jika dikaitkan dengan situs Batu Berak, maka dapat disimpulkan pula bahwa nilai-nilai tersebut Nampak pada situs Batu Berak dalam wujud bangunan-bangunan atau bendaa hasil karya manusia pada situs Batu Berak pada masa megalitikum. 
Menurut Galdrnen dalam (T. Abdullah, 2012) menyatakan bahwa kebudayaan megaliti yang masuk ke Indonesia dapat dibagi dalam dua gelombang. Gelombang pertama terjadi pada zaman Neolitik akhir kira-kira tahun 2.500-1.500 SM yang masuk ke Indonesia dibawa oleh imigran Tonkin menuju Malaysia Barat ke Sumatra selanjutnya berlanjut ke Jawa, Nuasa Tenggara dan menyebar ke Kalimantan.

Situs sejarah Batu Berak tersebut memiliki kelebihankelebiihan dan kekurangan dalam kaitannya keberadaannya sebagai sumber belajar. Meskipun demikian kekurangan yang dimiliki tidak serta membuat keberadaan situs batu bedil yang diiliki tidak serta merta membuat keberaadaan situs-situs tersebut menjadi layak untuk dimanfaatkaan. Salah satu kelebihan yang dimiliki situs tersebut sebagai sumber belajar yaitu situs batu bedil memiliki letak yang cukup strategis dimana dekat dengan tepi jalan raya sehinggaa akan memudahkan mahasiswa ingin melakukan lawatan sejarah terhadap situs-situs tersebut. Kelebihan yang lain yang dimiliki situs tersebut adalah kesesuaian materi yang terkandung dalam masingmasing situs dengan Standar Kompetensi dan Kompetensi Dasar yang ada dalam kurikulum

\section{Situs Batu Bedil}

Situs Batu Bedil secara administratif berada di Gunung Meraksa, kecamatan Pulau Panggung, Kabupaten Tanggamus. Secara geografis lokasi ini berada di wilayah hulu Way Sekampung. Bentag alam daerah berupa pedataran bergelombang. Situs Batu Bedil merupakan kompleks megalitik memiliki luas sekitar 100 x 500 m. Situs terbagi menjadi kompleks Batu bedil 1 berada di wilayah barat dan kompleks Batu Bedil II berada di wilayah timur. Kedua lokasi tersebut berjarak sekitar $100 \mathrm{~m}$. Kompleks Batu Bedil I berada pada lahan seluas 100 × 50 $\mathrm{m}$. Kompleks ini berada di lahan datar yang lebih tinggi dari daerah sekitarnya. Pada lahan ini terdapat prasasti dan sekelompok menhir yang membentuk formasi segi empat. Selain itu juga terdapat sebaran batu-batu besar.

Prasasti dituliskan pada sebongkah batu berukuran panjang $185 \mathrm{~cm}$, lebar $72 \mathrm{~cm}$, tebal $55 \mathrm{~cm}$. Tulisan prasasti digorsekan pada bagian batu yang menghadap ke utara. Prasasti terdiri atas 10 baris dengan tinggi huruf sekitar 5 $\mathrm{cm}$. Pada bagian bawah bingkai terdapat goresan membentuk Padma atau bunga tertai. Kondisi huruf sudah aus sehingga banyak huruf yang sudah tidak terbaca lagi. Di sebelah barat prasasti terdapat 14 menhir yang membentuk formasi segi empat. Menhir-menhir terebut merupakan batu alam yang tidak menunjukan tanda-tanda pengerjaan oleh manusia. Selain menhir di lahan ini juga terdapat sejumlah batu besar. Dilihat dari bentuknya batubatu tersebut kemungkinan sebagai menhir maupun dolmen. Pada permukaan lahan sering terlihat adanya benda artefaktual berupa pecahan keraik dan tembikar.

Situs Batu Bedil mengambarkan adanya persentuhan religi masyarakat dengan Buddha. Prasasti Batu Bedil berisi mantra. Tulisan pada prasasti Batu Bedil sudah sangat aus sehingg sulit dibaca. Berdasarkan perbandingan hurufnya. Prasasti Batu Bedil diperkirakan berasal dari akhir abad ke9 atau awal abad ke-10. Beberapa kata yang terbaca adalah Namo Bhagawate pada baris pertama Swaha pada baris ke sepuluh. Menurut Soekmono, berdasarkan kata-kata tersebut menunjukan bahwa Prasasti Batu Bedil berisi tentang mantra agama Budha (Soekmono, 1985).

Lokasi Prasasti Batu Bedil berada di lahan yang dibatasi dua sungai. Tingalan arkeologis lainnya yang ditemukan adalah bangunan megalitik. Di Batu Bedil I terdapat sekumpulan menhir, batu datar, dan prasasti sedangkan di
Batu Bedil II ditemukan menhir, dolmen, batu bergores, dan lumpang batu. Di antara tinggalan monumental tersebut tersebar pecahan keramik dan gerabah yang menunjukan bekas pemukiman. Berdasarkan kondisi seperti ini memperhatikan bahwa pada permukiman masyarakat terdapat juga monumen-monumen untuk sarana pemujaan kepada arwah nenek moyang. Lahan berupa punggungan bukit yang diapit dua aliran sungai merupakan lokasi ideal untuk permukiman karena secara alami sungai dapat dijadikan benteng pertahanan dan sekaligus menyediakan keperluan air. Kehidupan religi masyarakat ketika itu terlihat dari prasasti dan tinggalan monumental. Antara isi prasasti Batu Bedil dengan tinggalan arkeologis lain terlihat ada kesamaan watak yaitu menyangkut aspek religi. Isi prasati berupa mantra dalam ajaran Buddha sedangkan tinggalan monumental yang ada merupakan bangunan untuk sarana ritual dalam tradisi megalitik. Menhir, dolemen, batu datar, dan kaaitannya dengan sengaja di suatu tempat untuk memperingat arwah nenek moyang dan pengharapan kesejahteraan bagi yang masih hidup (Bintarti, 2010). Menurut H.R van Heekeren, dolmen merupakan peninggalan masyarakat pendukung budaya megalitik yang bis dikaitkan dengan upacara penguburan. Selain itu dolmen berfungsi sebagai tempat duduk yang dipergunakan dalm upacara pemujaan kepada arwah leluhur. Dolmen yang tersusun dengan peninggalan megalitik lainnya menunjukan bahwa olmen tersebut merupakan perangkat penting yang dipergunakan dalam kegiatan yang berhubungan dengan pemujaan arwah leluhur (Laili, 2004).

Situs sejarah Batu Bedil tersebut memiliki kelebihankelebiihan dan kekurangan dalam kaitannya keberadaannya sebagai sumber belajar. Meskipun demikian kekurangan yang dimiliki tidak serta membuat keberadaan situs batu bedil yang diiliki tidak serta merta membuat keberaadaan situs-situs tersebut menjadi layak untuk dimanfaatkaan. Salah satu kelebihan yang dimiliki situs tersebut sebagai sumber belajar yaitu situs batu bedil memiliki letak yang cukup strategis dimana dekat dengan tepi jalan raya sehinggaa akan memudahkan mahasiswa ingin melakukan lawatan sejarah terhadap situs-situs tersebut. Kelebihan yang lain yang dimiliki situs tersebut adalah kesessuaian materi yang terkandung dalam masingmasing situs dengan Standar Kompetensi dan Kompetensi Dasar yang ada dalam kurikulum.

\section{Bentuk pemanfaatan situs-situs sejarah di lampung sebagai sumber belajar untuk pembelajar sejarah pada Mahasiswa pendidikan sejarah}

Dari prinsip tersebut dapat dijadikan pedoman untuk melaksanakan pembelajaran dengan memanfaatkan kondisi lingkungan sekitar. Dengan memanfaatkan apa yang ada di alam sekitar sebagai sumber belajar, akan memberikan dampak yang baik terhadap mahasiswa dimana mereka akan lebih dapat memahami dan menguasai kondisi lingkungan sekitar mereka sehingga muncul pola pendidikan yang disesuiakan dengan kebutuhan lingkungan. Adanya otonomi pendidikan tersebut disebabkan karena munculnya fenomena bahwa tiap-tiap daerah memiliki ciri khas tersendiri baik dalam sifat, budaya, kemampuan siswa, kemampuan guru, kemampuan sekolah dalam mendukung pembelajaran dan pola pikirnya sehingga akan menjadi kurang bijaksana apabila pelaksanaan pembelajaran harus disamakan antar masing-masing daerah, lebih spesifik lagi antar satuan pendidikan. Penyamaan pembelajaran bagi semua daerah tentu akan menimbulkan kesenjangan bagi mereka yang sudah mampu melaksanakan pembelajaran dengan lebih 
maju dengan mereka yang hanya mampu melaksanakan pembelajaran secara konvensional sehingga perlu adanya penyesuaian yaitu melalui otonomi pendidikan tersebut.

Pelajaran sejarah sendiri tentunya memiliki kewenangan untuk dikembangkan sedemikian rupa sesuai dengan kebutuhan mahasiswa, lingkungan dosen dan tingkat satuan pendidikan itu sendiri sehingga sejarah dapat dikembangkan dengan sangat luas dalam bentuk pembelajarannya. Untuk mendapatkan pembelajaran sejarah yang maksimal, pembelajaran sejarah dapat dikembangkan dengan luas sesuai dengan apa yang sudah tercantum dalam kurikulum pendidikan sejaarah seperti yang telah dijelaskan sebelumnya. Termasuk pembelajaran sejarah yang ada di perguruaan tinggi, sudah seyogyanya pembelajaran sejarah yang ada di perguruan tinggi juga dikembangkan dengan luas sesuai potensi yang ada di Lampung. Terlebih lagi Lampung juga memiliki aset yang dapat digunakan untuk mengembangkan pembelajaran sejarah dengan lebih menarik dan lebih inovatif yaitu keberadaan situs-situs sejarah yang ada di Lampung. Keberaadaan situs-situs sejarah yang ada di Lampung seharusnya dapat digunakan sebagai sumber belajar untuk memperkaya pembelajaran sejarah yang dilaksanakan.

Pembelajaran sejarah sendiri banyak sekali mengalami kendala dalam pelaksanaanya, baik dari segi mahasiswa, dosen materi, waktu, maupun fasilitas pendukungnya. Sejarah perlu pembelajaran yang lebih menarik dan inovatif sehingga peserta didik dapat lebih maksimal dalam penyerapan materi, sebab dengan pembelajaran yang tidak menarik dan monoton akan muncul kebosanan pada mahasiswa, terlebih lagi sejarah yang membahas materi mengenai perjalanan masa lalu serta memiliki materi yang begitu banyak menyebabkan mahasiswa menjadi cenderung sulit untuk memahami keseluruhan materi. Padahal dari tuntutan kurikulum sendiri sudah ada acuan yang menyarankan untuk melaksanakan pembelajaran dengan memaksimalkan potensi dari masing-masing daerah, maka akan sangat disayangkan apabila pembelajaran sejarah yang ada masih monoton dan tidak inovatif. Hal tersebut dapat diatasi dengan menghindari pembelajaran yang yang hanya ceramah dan diskusi saja. Pembelajaran dengan memanfaatkan situs sejarah yang ada disekitar mereka akan dapat menjadi salah satu alternatif untuk menciptakan pembelajaran sejarah yang tidak monoton sebab pembelajaran dengan memanfaatkan situs sejarah sebagai sumber belajar dapat dilakukan dengan berbagai cara, selain itu mempelajari sesuatu yang dekat dengan kehidupan mahasiswa akan dapat lebih menarik minat mahasiswa. Seperti pernyataan Bapak Henry dalam wawancaranya yaitu sebagaiberikut:

"Peristiwa ataupun peninggalan sejarah yang terkait dengan anak, maka akan membuat anak menjadi lebih tertarik untuk mendalami dan ingin tau apa yang pernah terjadi disekitar mereka" (wawancara dengan Henry Susato, S.S,.M.Hum Agustus 2020).

Hal tersebut sesuai dengan apa yang diutarakan Isjoni dalam bukunya. Lingkungan di sekitar siswa terdapat berbagai peristiwa sejarah yang dapat membantu guru untuk mengembangkan pemahaman siswa tentang masa lalu. Umumnya siswa akan lebih tertarik terhadap pelajaran sejarah bila berhubungan dengan situasi nyata di sekitarnya, sehingga siswa dapat menggambarkan suatu peristiwa masa lalu seperti dalam pelajaran sejarah. Kondisi nyata di sekitar siswa dapat digunakan guru sebagai cara untuk menggambarkan atau mengantarkan suatu peristiwa sejarah (Isjoni, 2007:15).

Lampung memiliki berbagai macam peninggalan sejarah yang dapat digunakan sebagai sumber belajar, dimana dengan adanya peninggalan- peninggalan sejarah tersebut dapat dijadikan sebagai modal untuk mengembangkan pembelajaran yang lebih kreatif dan tidak monoton. Berbekal dukungan dari kurikulum dan ketersediaan situs sejarah yang ada di Lampung, dosen-dosen penddidikan sejarah di Lampung dapat memanfaatkan situs-situs tersebut sebagai sumber belajar untuk memperkaya pemahaman mahasiswa dengan materi yang berkaitan dengan situs tersebut. Pemanfaatan situs-situs sejarah yang ada di Lampung sebagai sumber belajar dapat dilakukan dengan berbagai macam dengan catatan pemanfaaan situs sejarah tersebut harus sesuai dengan fungsi dari sumber belajar sendiri. Di Program Studi pendidikan sejarah situs sejarah yang ada di Lampung dimanfaatkan masih dengan cara yang sederhana. Situs sejarah yang digunakan sebagai sumber belajar sendiri hanya situs pugung raharjo, sedangkan untuk peninggalan- peninggalan sejarah yang lain belum dimanfaatkan sebagai sumber belajar.

Mata pelajaran sejarah adalah suatu mata pelajaran yang berkaitan dengan peristiwa sejarah dimasa lampau, sedangkan peristiwa sejarah sendiri memiliki sifat einmalig atau hanya terjadi sekali dan tidak terulang lagi. Sifat dari sejarah yang hanya terjadi sekali dan tidak dapat terulang lagi, menyebabkan guru-guru sejarah harus memiliki cara yang terbaik untuk dapat memvisualisasikan fakta-fakta sejarah sehingga peristiwa sejarah itu dapat dipahami dengan baik oleh siswa dan tidak terjadi kesalahan dalam persepsi tiap- tiap siswa untuk merekonstruksi dalam pikiran mereka peristiwa sejarah yang mereka pelajari.

Menurut Soejatmoko dalam Isjoni (2007:79) langkah yang dapat ditempuh untuk dapat mengimajinasikan fakta-fakta sejarah atau memvisualisasikannya yaitu dengan mengembangkan metode riset dalam setiap pembelajarannya sehingga memungkinkan para siswa secara lansung terlibat sebagai pelaku dalam kegiatan penemuan dan pengkajian sejarah. Metode riset ini kadang disebut juga dengan discovery inquiry. Namun Isjoni dalam bukunya (2007:80) menyatakan bahwa metode yang paling tepat untuk digunakan dalam pembelajaran sejarah adalah metode penelitian sejarah

Untuk pendidikan sejarah sebaiknya menggunakan metode penelitian sejarah. Kalau metode discovery inquiry lebih menitikberatkan pada pengumpulan dan penyelidikan sumber-sumber yang relevan dengan materi pelajaran yang diajarkan, maka metode penelitian sejarah dapat berfungsi lebih dari itu, yakni pengumpulan dan penyelidikan sumber-sumber dan informasi yang berhubungan dengan suatu peristiwa sejarah yang sedang dipelajari siswa berdasarkan prosedur penelitian sejarah. Artinya sumber data yang berusaha dikumpulkan siswa adalah sumber data yang relevan dengan materi pelajaran melalui penerapan metode (penelitian) sejarah. (Isjoni, 2007).

Situs-situs sejarah yang ada di Lampung merupakan salah satu modal yang dapat digunakan untuk menerapkan metode penelitian sejarah. Situs-situs sejarah tersebut dapat digunakan sebagai sumber belajar yang berupa data primer dari peristiwa sejarah yang pernah terjadi di Lampung yang kemudian dapat dilakukan penelitian sejarah terhadapnya untuk merekonstruksi peristiwa sejarah yang terkandung dalam masing-masing situs tersebut. Namun untuk menerapkan metode penelitian sejarah tersebut tidak mudah sebab dalam melaksanakan metode penelitian sejarah dibutuhkan beberapa tahapan yang akan dilakukan oleh mahasiswa pendidikan sejarah.

“... selama ini saya hanya menggunakan media gambar untuk memanfaatkan situs sejarah yang ada di 
Lampung kalau datang langsung kesana, karena membutuhkan waktu sekitar 50-60 km-an. Dan membutuhkan waktu tenaga dan pikiran sehingga kalau mengarahkan mahasiswa untuk menunjungi situs-situs sejarah di Lampung itu harus dibagi menjadi beberapa kelompok karena jarak tempuh yang jauh dan antara situs satu dan lainnya berbeda daerah". (Wawancara dengan Henry Susanto Agustus 2020).

Selain akses jalan menuju situs sejarah di Lampung, kendala lain yang dirasakan oleh Bapak Henry adalah ketidak- sesuaian antara kandungan materi dalam situs sejarah di Lampung dengan alokasi waktu yang ada untuk materi yang sesuai dengan pokok bahasan mengenai Hindu-Budha. Berikut penuturan beliau:

"Situs sejarah di Lampung antara lain situs pugung raharjo, situs batu bedil dan situs batu berak kan kaitannya dengan materi Hindu-Budha, sedangkan untuk materi Hindu-Budha sendiri sangat banyak, situs tersebut hanya salah satu bagian kecil dari materi Hindu-Budha sehingga kalau terlalu fokus dengan situs tersebut, materi yang lain akan terbengkalai" (wawancara dengan Henry Susanto, Agustus 2020).

Kekurangan dalam aspek waktu sebenarnya dapat diatasi dengan memanfaatkan waktu diluar jam pelajaran, namun hal tersebut tampaknya masih belum dilaksanakan oleh Bapak Henry dengan alasan terlalu besar resikonya apabila melaksanakan pembelajaran diluar jam pelajaran, terlabih lagi sulit mengatur jadwalnya karena anak-anak juga harus mengikuti kegiatan yang lain. (Henry Susanto Agustus, 2020)

Masing-masing tentunya memiliki kendala yang berbeda dalam hal pelaksanaan pembelajaran dengan memanfaatkan situs sejarah sebagai sumber belajar, mengingat masing-masing memiliki kondisi yang berbedabeda baik dari aspek dosen, mahasiswa, fasilitas kampus, maupun sistem pembelajaran yang diterapkan. Perbedaan itu nantinya akan membawa pengaruh pula pada kendala yang dihadapi. Sebab dalam suatu pembelajaran, seluruh komponen pembelajaran memiliki peran penting dan saling terkait satu sama lain sehingga keberadaan masingmasing komponen pembelajaran tersebut tidak dapat dipisahkan serta membawa dampak yang signifikan pula terhadap proses pembelajaran yang dilaksanakan. Termasuk didalamnya pembelajaran dengan memanfaatkan situs sejarah sebagai sumber belajar. Masing-masing komponen tadi akan membawa pengaruh dalam pelaksanaan pembelajaran dengan memanfaatkan situs sejarah. sebagai sumber belajar yang nantinya akan menimbulkan dampak yang berbeda pula pada kendala yang dihadapi.

Adanya kendala dalam pelaksanaan pemanfaatan situs sejarah yang ada di Lampung sebagai sumber belajar juga dirasakan oleh Bapak Sumargono dosen prodi pendidikan sejarah yang sudah memanfaatkan situs sejarah sebagai sumber belajar. Berikut penuturan bapak Sumargono mengenai kendala yang dihadapi dalam memanfaatkan situs sejarah di Lampung:

\footnotetext{
"kalau hanya sebatas penggunaan video pembelajaran tentu tidak mengalami kesulitan, tetapi kalau harus terjun ke lapangan itu yang agak sulit apabila harus mengikutkan mahasiswa semuanya. Katakanlah seperti kunjungan sejarah secara klasikal, kendala yang pertama yaitu waktunya dan yang kedua yaitu pemanfaatan dengan cara itu harus mengeluarkan biaya yang cukup besar" (Sumargono, Agustus 2020).
}

Kendala waktu juga ditemukan bapak Sumargono dalam hal alokasi waktu pembelajaran sejarah yang beliau laksanakan.

\section{KESIMPULAN}

Memanfaatkan situs sejarah sebagai sumber belajar merupakan hal penting, sebab situs sejarah merupakan salah satu sumber sejarah yang dapat memberikan gambaran suatu peristiwa dengan lebih konkrit kepada mahasiswa. Lampung memiliki beberapa situs sejarah yang dapat digunakan sebagai sumber belajar dan situs-situs sejarah di Lampung memiliki kesesuaian antara materi yang terkandung dalam situs dengan materi perkuliahan yang ada pada kurikulum Program Studi Pendidiakn Sejarah FKIP Universitas Lampung.

\section{DAFTAR PUSTAKA}

Abdullah, R. (2012) 'Pembelajaran Berbasis Pemanfaatan Sumber Belajar', Jurnal IImiah Didaktika, 12(2), pp. 216231. doi: $10.22373 /$ jid.v12i2.449.

Andres, M. and Fakhri, A. (2020) 'Pemanfaatan dan Pemaknaan Situs Sejarah Tugu Medan Area di Kota Medan', Jurnal JRPP, Vol. 3(No. 1), pp. 1-9.

Arief. S. Sadiman, dkk (2006) No TitleMedia pendidikan, Pengertian, Pengembangan dan pemanfaatannya. Jakarta: PT. Raja Grafindo Persada.

Asmar, T. et al (1975) Sejarah Jawa Barat Dari Masa Pra Sejarah Hingga Masa Penyebaran Islam. Bandung. Jawa Barat: Proyek Penunjang Peningkatan Kabupaten Nasional Provinsi Jawa Barat.

Asmara, Y. (2018) 'Penguatan Pendidikan Karakter Melalui Pembelajaran Sejarah Di Era Revolusi Industri 4.0', Seminar Nasional Sejarah ke-4 Jurusan Pendidikan Sejarah Universitas Negeri Padang, 216-227.

Ayuningtyas, T.R Hilmiah, A. S., \& Rohmawati, R. (2018) 'Pemanfaatan Situs Peninggalan Sejarah Di Kabupaten Bondowoso Sebagai Sumber Belajar Di Sekolah Lanjutan Tingkat Atas Di Kabupaten Bondowoso.', Jurnal HISTORIA, 6(1), 139-150.

Azaryahu, M., \& Foote, K. E. (2008) 'Historical space as narrative medium: on the config- uration of spatial narratives of time at historical sites', GeoJournal, 73(3), 179-194.

Basri, M. et al. (2020) 'Nilai-Nilai Sejarah Berbasis Local Wisdom Situs Batu Berak Sebagai Sumber Pembelajaran Sejarah', Gulawentah: Jurnal Studi Sosial, 5(2), p. 125. doi: 10.25273/gulawentah.v5i2.7241.

Brophy, J. E., \& VanSledright, B. (1997) Teaching and learning history in elementary schools. Teachers College Press.

Cahyono, Y. D. (2014) Strategi Pembelajaran Sejarah Peristiwa 1965 Untuk Tingkat SMA. Historia Viate Seri Pengetahuan dan Pengajaran Sejarah.

F, A. N. (2016) 'Pengembangan Media Pembeajaran Sejarah Berbasis Media Audio Visual Situs Purbakala Pugung Raharjo Untuk Meningkatkan Kesadaran Sejarah Siswa Kelas X SMA Negeri Kota Gajah.', Jurnal IImiah Dikdaya, 6 (2). doi: DOI: http://dx.doi.org/10.33087/dikdaya.v6i1.

Firmansyah, H. (2021) 'Pemanfaatan Bangunan Cagar Budaya di Area Duizen Vierkanten Paal Kota Pontianak sebagai 
Sumber Pembelajaran Sejarah', Fajar Historia: Jurnal IImu Sejarah dan Pendidikan, 5(1), pp. 15-28. doi: 10.29408/fhs.v5i1.3554.

Gagne, R. M. (1984) Kondisi Belajar dan Teori Pembelajaran. Depdikbud. Edited by Terjemahan Munandir. Jakarta.

Harrison, L. H. (1967) Local history as a teaching technique. Peabody Journal of Education, 45(1), 6-8.

Hasan, Said, H. (1985) Evaluasi Kurikulum. Jawa Barat: Depdikbud-Dirjen Dikti P2LPTK.

Kartodirjo, S. (1993) Pendekatan IImu Sosial dalam Metodologi Sejarah. Edited by Gramedia Pustaka Utama. Jakarta.

Maslina, N. (2018) 'Situs sejarah an Fungsingnya Dalam Pembelajaran Sejarah di SMA Kecamatan Lut Tawar. Kabupaten Aceh Tengah', Skripsi.

Mukti, F. (1993) Media Pengajaran. Proyek Pem. Jakarta.

Nababan, S. A., Agung, L., \& Yamtina, S. (2019) 'Pemanfaatan Situs Kota Cina Sebagai Sumber Permbelajaran Sejarah Lokal di Kota Medan', Jurnal ekonomi, sosial \& humaniora, $1(4), 49-55$.

Nana Syaodih Sukmadinata (2010) Metode Penelitian Pendidikan. Edited by P. R. Rosdakarya. Bandung.

Nandia, A., Waluyo, H. J. and Haryanto, S. (2016) 'Pengembangan Media Pembelajaran Sejarah Berbasis Media Audio Visual Situs Purbakala Pugung Raharjo Untuk Meningkatkan Kesadaran Sejarah Siswa Kelas X Sma Negeri 1 Kotagajah', Jurnal IImiah Dikdaya, pp. 29-45.

Nata, A. (2009) Perspektif Islam tentang Strategi Pembelajaran. Kencana Pr. Jakarta.

Nichols, H. B. (1930) The Importance of Local History in The Schools and Methods of Teaching It. The Quarterly Journal of the New York State Historical Association, 11(1), 53-62.

Paramita, A., Patahuddin, P., \& Ridha, R. (2019) 'Situs Jera' Lomp'e Sebagai Sumber Belajar Sejarah Siswa Kelas X SMAN 8 Soppeng.', PATTINGALLOANG, 6(3), 1-7. 10.26858/pattingalloang.v6i3.11684.

Pelealu, A. E. (2019) 'Sumber Belajar Sejarah: Pemanfaatan Situs Cagar Budaya di Minahasa', Seminar Nasional Sejarah Ke 4 Jurusan Pendidikan Sejarah Universitas Negeri Padang, 719-729.

Pendidikan, D. et al. (2018) 'LANJUTAN TINGKAT ATAS DI KABUPATEN BONDOWOSO Tantri Raras Ayuningtyas Anis Syatul Hilmiah Rina Rohmawati PENDAHULUAN Kabupaten Bondowoso secara geografis terletak di ujung sebelah timur pulau Jawa yang merupakan daerah tapal kuda Karisidenan Besuki . Bond', 6.

Perdana Y., Sumargono, \& Rachmedita, V. (2019) 'Integrasi Sosiokultural Siswa dalam Pendidikan Multikultural Melalui Pembelajaran Sejarah', Jurnal PENDIDIKAN SEJARAH, 8(2), 79-98.

Peters, R. S. (2009) 'Education and human development', Education and the Development of Reason, 8(2), 373-387. $10.4324 / 9780203861165$

Purnamasari, I. (2011) 'Pengembangan Model Pembelajaran Sejarah Berbasis Situs Sejarah Lokal di SMA Negeri Kabupaten Temanggung,, Paramita: Historical Studies Journal, 21(2).

Rafika, A. S. and Amboro, K. (2019) 'Pengembangan Desain Media Pembelajaran Sejarah Movie Maker Berbasis Visualisasi Situs Megalitik Pugung Raharjo Lampung ...', Swarnadwipa, 2, pp. 99-108.

Roestiyah N. K. (2001) Strategi Belajar Mengajar. Edited by Rineka Cipta. Rineka Cipta.
Rokhim, M. A., Banowati, E. and Setyowati, D. L. (2017) 'Pemanfaatan Situs Masjid Agung Demak sebagai Sumber Belajar Sejarah bagi Siswa SMA di Kabupaten Demak', Journal of Educational Social Studies, 6(2), 111-119.

Santosa, Y. B. P. (2017) 'Problematika Dalam Pelaksanaan Pendidikan Sejarah Di Sekolah Menegah Atas Kota Depok', Candrasangkala: Jurnal Pendidikan dan Sejarah, 3(1),. doi: 30-36. 10.30870/candrasangkala.v3i1.2885.

Seixas, P., \& Peck, C. (2004) Teaching historical thinking. Challenges and Prospects for Canadian Social Studies, 109 117.

Sejarah, S. N. et al. (2000) '448 | Seminar Nasional Sejarah ke 4 Jurusan Pendidikan Sejarah Universitas Negeri Padang', pp. 448-458.

Septiani, A. (2016) 'Situs Astana Gede Kawali Sebagai Sumber Belajar Bagi Mahasiswa Sejarah', Candrasangkala: Jurnal Pendidikan dan Sejarah, 2(1), pp. 27-36.

Shipton, C. et al. (2012) 'Lithic technology and social transformations in the South Indian Neolithic: The evidence from Sanganakallu-Kupgal', Journal of Anthropological Archaeology. Elsevier Inc., 31(2), pp. 156173. doi: 10.1016/j.jaa.2011.11.003.

Siska, Y. (2017) 'Peninggalan Situs Megalitik Sekala Brak Dan Implikasinya Dalam Pembelajaran Sejarah Lokal Di Sekolah Dasar', Mimbar Sekolah Dasar, 4(2), pp. 172-181. doi: 10.23819/mimbar-sd.v4i2.6489.

Sulistyo, W. D. (2019) 'Learning Activities from Learning Resources: Pemanfaatan dan Pemaknaan Situs Sejarah Kawasan Alun-Alun Merdeka Kota Malang Pemanfaatan dan Pemaknaan Situs Sejarah Kawasan Alun-Alun Merdeka Kota Malang', Jurnal Pendidikan Sejarah Indonesia, 2(1), pp. 49-63. doi: 10.17977/um033v2i12019p049.

Sumarno (2002) 'Situs Sejarah di Kabupaten Bondowoso dan Pemanfaatannya sebagai Media Pembelajaran Sejarah di Sekolah', Jurnal Pancaran Pendidikan., 5(1), pp. 13-21.

Syah, M. (2010) Psikologi Pendidikan dengan Pendekatan Baru. Bandung: Remaja Rosdakarya.

Syaputra, M. A. D., Sariyatun, S. and Ardianto, D. T. (2020) 'Pemanfaatan Situs Purbakala Candi Muaro Jambi Sebagai Objek Pembelajaran Sejarah Lokal Di Era Digital', Jurnal Pendidikan Sejarah Indonesia, 3(1), p. 77. doi: 10.17977/um0330v3i1p77-87.

Trianto. (2010) Mendesain Model Pembelajaran InovatifProgresif. Jakarta: Kencana Prenada.

'Undang-undang RI. Tentang Cagar Budaya, Pub. L. No. 11' (2011).

Warsito (2012) Peningkatan Motivasi dan Hasil Belajar Matematika Melalui Pendekatan Kontruktivisme Dengan Mengoptimalkan Media Information and Communication Technologies (ICT). Skripsi. Surakarta.

Wasino (2009) Pokok Pikiran Untuk Menulis Sejarah Lokal. Makalah Sarahsehan dan Koordinasi dan Curah Pendapat Sejarah Lokal Untuk Meningkatkan Wawasan Kebangsaan Deputi Menko Kesra Bidang Koordinasi Kebudayaan Pariwisata, Pemuda dan Olah Raga. Patra Jasa Semarang, 24 $M$. Semarang.

Yenshu Vubo, E. (2003) 'Levels of historical awareness: The development of identity and ethnicity in Cameroon', Cahiers d'Etudes Africaines, 43(3), pp. 591-628. doi: 10.4000/etudesafricaines.217.a 
Journal of Research in Social Science and Humanities, 1(2), December 2021, - 70 